Suska Journal of Mathematics Education

Vol.2, No. 1, 2016, Hal. $52-56$

\title{
Pengaruh Pembelajaran Matematika Menggunakan Strategi Inkuiri Terhadap Kemampuan Pemecahan Masalah Matematika
}

\author{
Lies Andriani \\ Program Studi Pendidikan Matematika, Fakultas Tarbiyah dan \\ Keguruan, UIN Sultan Syarif Kasim Riau \\ Email: liesandriani@yahoo.co.id
}

\begin{abstract}
ABSTRAK. Penelitian ini bertujuan untuk mengetahui apakah terdapat perbedaan kemampuan pemecahan masalah matematika antara mahasiswa yang belajar menggunakan strategi inkuiri dengan mahasiswa yang memperoleh pembelajaran secara konvensional pada mata kuliah Telaah Materi Matematika SMA. Penelitian ini merupakan penelitian quasi eksperimen, karena dalam desain ini peneliti tidak dapat mengontrol semua variabel yang mempengaruhi jalannya eksperimen. Dalam penelitian ini, peneliti berperan langsung sebagai dosen dalam proses pembelajaran. Subjek dalam penelitian ini adalah mahasiswa kelas IVB dan mahasiswa kelas IVD Prodi Pendidikan Matematika yang berjumlah 69 orang dan objek penelitian ini adalah pemecahan masalah matematika mahasiswa. Pengambilan data dalam penelitian ini menggunakan dokumentasi, lembar observasi, dan tes. Untuk mengetahui hasil penelitian tersebut digunakan rumus tes-t. Berdasarkan hasil analisis data dapat disimpulkan bahwa terdapat perbedaan kemampuan pemecahan masalah matematika antara mahasiswa yang belajar menggunakan strategi inkuiri dengan mahasiswa yang memperoleh pembelajaran secara konvensional pada mata kuliah Telaah Materi Matematika SMA.
\end{abstract}

Kata kunci : strategi pembelajaran inkuiri, kemampuan pemecahan masalah, matematika 


\section{PENDAHULUAN}

Matematika bertujuan agar peserta didik memiliki kemampuan dalam memecahkan permasalahan. Mahasiswa sebagai salah satu komponen dalam pendidikan harus selalu dilatih dan dibiasakan berpikir mandiri untuk memecahkan masalah. Hal ini dikarenakan pemecahan masalah, selain menuntut siswa untuk berpikir juga merupakan alat utama untuk melakukan atau bekerja dalam matematika (Saptuju, 2005: 14).

Menurut Ade Yuniarsa Nugraha bahwa jika diteliti, komposisi dari soal-soal Trends in International Mathematics and Science Study (TIMSS) (1999, 2003, 2007) yang diujikan didominasi oleh soal-soal pemecahan masalah, dimana soalsoal pemecahan masalah inilah yang menjadi titik lemah siswa Indonesia yang menyebabkan kecilnya skor yang diperoleh. Hal ini sejalan dengan hasil pengkajian Badan Pengembangan Sumber Daya Manusia Pendidikan dan Penjaminan Mutu Pendidikan (2011:55) yang mengacu kepada hasil TIMSS dimana salah satu kesimpulannya menyebutkan bahwa siswa kita lemah dalam mengerjakan soal-soal yang menuntut kemampuan pemecahan masalah dan lemah dalam soal aplikasi yang menuntut suatu cerita. Kemampuan pemecahan masalah merupakan bagian dari kemampuan berpikir tingkat tinggi.

Hal tersebut juga sejalan permasalahan yang terjadi di tingkat perguruan tinggi khususnya pada program studi pendidikan matematika, yakni yang dialami oleh mahasiswa semester IV. Permasalahan yang dialami oleh mahasiswa tersebut adalah kurangnya kemampuan siswa dalam memecahkan masalah matematika. Dalam menghadapi permasalahan tersebut, dosen sudah mengupayakan perbaikanperbaikan untuk meningkatkan proses pembelajaran. Usaha yang dilakukan dosen seperti dengan menerapkan strategi pembelajaran yang bervariasi, tetapi kenyataannya hal itu belum berpengaruh pada proses pembelajaran.

Berkaitan dengan pentingnya mencapai tujuan pembelajaran matematika, khususnya menumbuhkembangkan kemampuan pemecahan masalah matematika, hendaknya ada suatu cara yang dilakukan agar tujuan tersebut tercapai. Salah satu hal yang bisa dilakukan adalah seperti menerapkan strategi pembelajaran yang cocok dalam proses pembelajaran matematika. Hal ini bisa dilakukan karena dalam proses pembelajaran, guru dituntut menerapkan strategi pembelajaran agar tujuan pembelajaran matematika tercapai.

Salah satu strategi pembelajaran yang dapat menumbuhkembangkan kemampuan pemecahan masalah adalah startegi pembelajaran inkuiri. Strategi pembelajaran inkuiri merupakan salah satu pembelajaran dengan pendekatan kontruktivisme dan berpusat pada siswa (student centered). Oleh karena itu, siswa harus aktif dalam proses pembelajaran. Hal ini sejalan dengan pendapat Budiningsih (2008:58) bahwa peserta didik harus aktif melakukan kegiatan, aktif berfikir, menyusun konsep, dan memberi makna tentang hal-hal yang sedang dipelajari.

Strategi pembelajaran inkuiri merupakan suatu rangkaian kegiatan belajar yang melibatkan secara maksimal seluruh kemampuan siswa untuk mencari dan 
menyelidiki secara sistematis, kritis, logis, analitis, sehingga mereka dapat merumuskan sendiri penemuannya dengan percaya diri. Pada pembelajaran inkuiri, pertama kali siswa dihadapkan pada permasalahan atau pertanyaan yang kemudian siswa akan merumuskan hipotesis dari permasalahan tersebut. Kemudian siswa mengumpulkan data dan menganalisis data untuk ditarik sebuah kesimpulan atau pemecahan dari permasalahan tersebut. Wena(2011 :81) menyatakan bahwa berdasarkan hasil penelitian tentang pembelajaran inkuiri yang telah banyak dilakukan di Indonesia menunjukkan model inkuiri secara signifikan dapat meningkatkan hasil belajar siswa dan sekaligus meningkatkan kemampuan pemecahan masalah.

Berdasarkan paparan tersebut, maka secara teoretik dapat dikatakan bahwa pembelajaran inkuiri dapat meningkatkan kemampuan pemecahan masalah matematika. Oleh karena itu, peneliti berasumsi bahwa strategi pembelajaran inkuiri dapat meningkatkan kemampuan pemecahan masalah matematika. Berdasarkan asumsi tersebut, rumusan masalah pada peneitian ini adalah apakah terdapat pengaruh pembelajaran matematika dengan menggunakan strategi inkuiri terhadap kemampuan pemecahan masalah matematika.

\section{METODE PENELITIAN}

Penelitian ini adalah penelitian quasi eksperimental, dengan desain Posttestonly Design with Nonequivalent Group. Desain ini memiliki satu kelompok eksperimen yang diberikan suatu perlakuan dan diberi posttest, tetapi tanpa pretest, dan satu kelompok kontrol yang hanya diberikan posttest tetapi tanpa pretest dan tanpa perlakuan (Slamet, 2008: 102).

Penelitian ini dilaksanakan di Prodi Pendidikan Matematika pada kelas matakuliah Telaah Materi Matematika SMA semester genap TA. 2011/2012. Jumlah kelas pada matakuliah Telaah Materi Matematika SMA terdapat empat kelas. Untuk memilih sampel penelitian maka dilakukan dengan teknik sampel pertimbangan yaitu teknik penentuan sampel dengan pertimbangan tertentu (Sugiyono, 2011: 124). Adapun sampel dalam penelitian ini adalah kelas IV D sebagai kelas eksperimen dan IV B sebagai kelas kontrol.

Sedangkan teknik pengumpulan data yang digunakan dalam penelitian adalah teknik tes, dokumentasi, dan observasi. Analisis data tentang perbandingan hasil belajar matematika siswa sesudah penerapan strategi pembelajaran inkuiri dalam penelitian ini yang digunakan adalah tes " $t$ ". Tes "t" adalah salah satu uji statistik yang digunakan untuk mengetahui ada atau tidaknya perbedaan yang signifikan dari dua variabel yang dikomparatifkan (Hartono, 2010: 178). Sebelum melakukan analisis data dengan tes-t, ada dua syarat yang harus dilakukan yaitu: uji normalitas dan homogenitas. 


\section{HASIL PENELITIAN DAN PEMBAHASAN}

Hasil analisis data yang diperoleh skor mean kelas eksperimen sebesar 75,833 dan skor mean kelas kontrol sebesar 68,667. Hal ini menunjukkan bahwa skor mean kelas eksperimen lebih tinggi daripada skor mean kelas kontrol. Kemudian dilanjutkan analisis data dengan tes " $\mathrm{t}$ " untuk $\mathrm{n}_{1} \neq \mathrm{n}_{2}$ dan varian tidak homogen. Hasil perhitungan selengkapnya dapat dilihat pada table berikut:

\begin{tabular}{|c|c|c|c|c|c|c|}
\hline \multicolumn{1}{|c|}{ Tabel 1. Hasil Uji Tes “t” } \\
\hline Kelas & Perbedaan & $\mathrm{t}_{\text {hitung }}$ & $\mathrm{dk}_{1}$ & $\mathrm{dk}_{2}$ & $\mathrm{t}_{\text {tabel }}$ & Ho \\
\hline $\begin{array}{c}\text { Eksperimen } \\
\text { Kontrol }\end{array}$ & $75.833>68.667$ & 2.093 & 35 & 32 & 2,0315 & Tolak \\
\hline
\end{tabular}

Dari Tabel 1, dapat diambil keputusan yang dilakukan dengan cara membandingkan nilai $t_{\text {hitung }}$ dengan $t_{\text {tabel }}$, dengan ketentuan sebagai berikut:

Jikat $_{\text {hitung }}<\mathrm{t}_{\text {tabel }}$, maka $\mathrm{H}_{0}$ diterimadan $\mathrm{H}_{\mathrm{a}}$ ditolak.

Jikat $_{\text {hitung }}>\mathrm{t}_{\text {tabel }}$, maka $\mathrm{H}_{0}$ ditolakdan $\mathrm{H}_{\mathrm{a}}$ diterima.

Selanjutnya $\mathrm{t}_{\text {hitung }}$ tersebut dibandingkan dengan $\mathrm{t}_{\text {tabel }}, \mathrm{n}=36$; dengan $\mathrm{dk}=35$, maka harga $\mathrm{t}_{\text {tabel }}$ untuk signifikan $5 \%=2.021$. Kemudian, $\mathrm{n}=33$; dengandk $=32$, maka harga $t_{\text {tabel }}$ untuk signifikan $5 \%=2.042$. Jadi, harga $t_{\text {tabel }}$ yang digunakan adalah: $(2.042-2.021) / 2=0.0105$. Selanjutnya ditambah dengan harga t yang terkecil. Jadi, $2.021+0.0105=2.0315$. Harga $t=2.0315$ inilah sebagai pengganti harga $t_{\text {tabel. }}$.

Dalam hal ini berlaku ketentuan bahwa bila $t_{\text {hitung }}$ lebih besar atau sama dengan $t_{\text {tabel }}$, maka Ha diterima. Ternyata $t_{\text {hitung }}$ lebih besar daripada $t_{\text {tabel }}(2.093>$ 2.0315). Dengan demikian, Ha diterima dan Ho ditolak. Artinya, terdapat perbedaan kemampuan pemecahan masalah antara mahasiswa yang belajar menggunakan strategi inkuiri dengan mahasiswa yang memperoleh pembelajaran konvensional.

Berdasarkan data kemampuan pemecahan masalah matematika mahasiswa pada pokok bahasan barisan dan deret menunjukkan bahwa mean kemampuan pemecahan masalah kelas yang menggunakan strategi inkuiri lebih tinggi dari mean kemampuan pemecahan masalah kelas yang menggunakan pembelajaran konvensional. Dari perhitungan tes "t" diperoleh th lebih besar dari tt pada taraf signifikan 5\%. Hal ini menunjukkan bahwa penerapan strategi inkuiri dalam pembelajaran matematika menyebabkan adanya perbedaan kemampuan pemecahan masalah matematika mahasiswa khususnya pada mata kuliah telaah materi SMA. Di mana kemampuan pemecahan masalah kelas eksperimen lebih tinggi dari kelas kontrol. Perbedaan mean kedua variabel menunjukkan bahwa penggunaan strategi inkuiri lebih baik dari pada pembelajaran konvensional. Dengan demikian, hasil analis ini mendukung rumusan masalah yaitu ada perbedaan kemampuan pemecahan masalah matematika mahasiswa yang mengikuti strategi inkuiri dengan mahasiswa yang mengikuti pembelajaran konvensional. 


\section{KESIMPULAN}

Berdasarkan hasil penelitian, dapat diambil kesimpulan sebagai berikut: terdapat perbedaan pemecahan masalah matematika antara mahasiswa yang belajar menggunakan strategi inkuiri dengan mahasiswa yang mengikuti pembelajaran konvensional. Hal ini terlihat dari mean yang diperoleh oleh kedua kelas, di mana mean kelas eksperimen sebesar 75.833 dan mean kelas kontrol sebesar 68.667. Di samping itu, nilai $t_{\text {hitung }}>t_{\text {tabel }}(2.093>2.0315)$.

\section{DAFTAR PUSTAKA}

Budiningsih, C.A. (2008). Belajar dan Pembelajaran. Jakarta : Rineka Cipta

Departemen Pendidikan Nasional. (2006). Model Penilaian Kelas. Jakarta : BSNP

Hartono. (2010). Statistik untuk Pendidikan. Yogyakarta : Pustaka Pelajar.

Suryosubroto, B. (2002). Proses Belajar Mengajar di Sekolah. Jakarta : Rineka Cipta.

Wena, M. (2011). Strategi Pembelajaran Inovatif Kontemporer. Jakarta : Bumi Aksara.

Saptuju. (2005). Meningkatkan kemampuan Siswa SMP dalam menyelesaikan Soal Cerita Matematika Melalui Belajar Kelompok Kecil dengan Pendekatan Problem solving. Tesis Universitas Pendidikan Indonesia. Tidak diterbitkan.

Sugiyono. (2010). Metode Penelitian Kuantitif Kualitatif dan $R \& D$. Bandung : Alfabeta. 